\title{
Oddziaływanie paliwa etanolowego E85 na właściwości użytkowe oleju silnikowego
}

\begin{abstract}
W artykule przedstawiono wyniki prac, których celem było określenie stopnia degradacji smarowego oleju silnikowego eksploatowanego w silniku o zapłonie iskrowym typu flex fuel, zasilanym paliwem wysokoetanolowym składającym się z $85 \%(V / V)$ bioetanolu pierwszej generacji i z 15\% (V/V) konwencjonalnej benzyny węglowodorowej. Jako obiekt badań wytypowano olej silnikowy zalecany do smarowania tego rodzaju silników, o klasie lepkości SAE 5W-30 i klasie jakości ACEA A5/B5. Monitorowanie właściwości przedmiotowego oleju prowadzone było w czasie trwania testu silnikowego (po 100 i 600 godzinach pracy), jak również po jego zakończeniu (tj. po 1100 godzinach rzeczywistej pracy silnika).
\end{abstract}

Słowa klucze: paliwo etanolowe E85, olej silnikowy, procesy degradacji.

\section{Impact of E85 ethanol fuel on engine oil properties}

The article presents results of work aimed at determining the degree of degradation of a lubricating engine oil used in spark ignition Flex Fuel automobile engine (FFV). The FFV engine was powered by a high-ethanol fuel consisting of $85 \%(V / V)$ of first-generation bioethanol and 15\% $(V / V)$ of conventional hydrocarbon gasoline. As an object of the study, an engine oil was recommended for this type of engine lubrication, the SAE 5W-30 viscosity grades and ACEA A5/B5 quality grade engine oil was selected. Monitoring of the properties of the subjected oil was carried out during the engine test after 100 and 600 hours of operation, as well as after its completion, e.g. after 1100 hours of real engine operation.

Key words: E85 ethanol fuel, engine oil, degradation processes.

\section{Wstęp}

Pomysł wykorzystania alkoholu do zasilania silników spalinowych zrodził się już w XIX wieku. W pierwszych zasto-

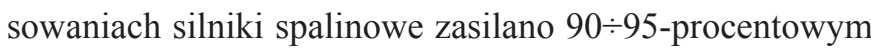
spirytusem. Jednak mające miejsce w kolejnych latach odkrycie złóż ropy naftowej, gwałtowny wzrost jej wydobycia oraz opracowanie efektywnych technologii jej przeróbki spowodowały wyparcia alkoholu jako paliwa. Współcześnie, ze względu na aspekt ochrony środowiska, zainteresowano się ponownie paliwami alternatywnymi, w tym również alkoholem, którego stosowanie przyczynia się między innymi do ograniczenia emisji $\mathrm{CO}_{2}[1]$.

Bioetanol otrzymywany jest na drodze procesów hydrolizy i fermentacji surowców zawierających cukry proste (np. melasa, serwatka) lub polisacharydy (np. skrobia, celuloza).
W przyszłości substancjami mogącymi znaleźć zastosowanie do tego celu będą odpadowe surowce celulozowe, które do tej pory nie są powszechnie wykorzystywane ze względu na wysokie koszty hydrolizy.

Polska posiada znaczne ilości surowców odnawialnych, które można użyć do produkcji bioetanolu. Jednak obecnie możliwości wytwarzania tego biopaliwa są ograniczone brakiem dostatecznej bazy przetwórczej (rysunek 1).

Największe doświadczenie na świecie w produkcji i stosowaniu benzyny silnikowej z udziałem etanolu ma Brazylia. Popularne są tam zarówno paliwa zawierające 24\% (V/V) etanolu (E24), jak i paliwa stanowiące w 100\% etanol (E100) [3].

W USA - drugim na świecie producencie etanolu (43\% światowej produkcji), począwszy od lat osiemdziesiątych 


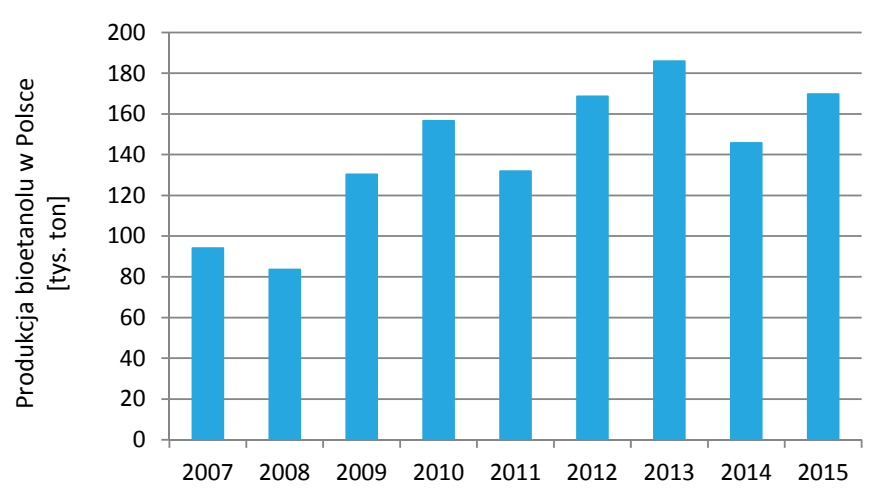

Rys. 1. Produkcja bioetanolu w Polsce w latach 2007-2015 [6]

ubiegłego wieku stosowanie etanolu i innych związków tlenowych zostało obligatoryjnie wdrożone poprzez U.S. Department of Energy's - Energy Policy Act z 1992 roku [11]. Według tego dokumentu paliwo E85 jest uznawane za alternatywne.

W Europie najbardziej zaawansowanym krajem w zakresie praktycznego wykorzystania etanolu jako komponentu do benzyn silnikowych jest Szwecja, gdzie oprócz benzyny silnikowej z udziałem 5\% (V/V) etanolu produkowane jest również paliwo etanolowe E85 [2]. Wiele instalacji do produkcji etanolu powstało także na terenie Hiszpanii, Niemiec, Holandii i Wielkiej Brytanii [9].

W przypadku biopaliw zawierających do $85 \%(V / V)$ etanolu różnice pomiędzy właściwościami fizykochemicznymi i użytkowymi są tak duże w porównaniu $\mathrm{z}$ tradycyjnymi benzynami silnikowymi, że wymuszają wprowadzenie wielu zmian konstrukcyjno-materiałowych i regulacyjnych w silniku, w celu dostosowania go do eksploatacji na takich paliwach - tablica $2[7,8,10]$. Fabrycznie przystosowane do tego typu paliw pojazdy mogą być zasilane zarówno biopaliwem E85, jak i konwencjonalną benzyną silnikową i dlatego nazywane są Flex Fuel Vehicles (FFV). Do najistotniejszych zmian konstrukcyjnych w silnikach takich samochodów należą: zastosowanie specjalnych stopów do produkcji tłoków, pierścieni tłokowych i tulei cylindrowych, ze względu na wyższe średnie temperatury i ciśnienia spalania oraz odmienne środowisko chemiczne, w którym pracują te elementy. Używany w tego typu silnikach olej smarujący powinien charakteryzować się polepszonymi właściwościami detergentowo-dyspergującymi, a okresy pomiędzy jego wymianami powinny być skrócone [10].

Jakość oleju silnikowego w coraz większym stopniu przekłada się na osiągi silnika, właściwości użytkowe, trwałość i wielkość emisji toksycznych składników spalin. Jest on również jednym z nośników informacji o stanie technicznym jednostki napędowej i przebiegu eksploatacyjnym, a jego analiza pozwala na ocenę warunków, w jakich silnik był smarowany.

Współczesny olej silnikowy stanowi integralny element konstrukcyjny silnika. $Z$ uwagi na różne warunki pracy oraz złożoną kinetykę silnika olej smarowy pełni następujące zadania [4]:

- wypełnia wszystkie nierówności na powierzchniach współpracujących elementów,

- zapewnia płynne smarowanie, czyli oddzielenie powierzchni współpracujących, a tym samym zmniejsza tarcie i zużycie powierzchni trących oraz pozwala przenosić obciążenia,

- chłodzi silnik od wewnątrz,

- uszczelnia przestrzeń spalania,

- zabezpiecza elementy metalowe przed korozją,

- odprowadza produkty zużycia od trących i zużywających się elementów ciernych,

- rozpuszcza i zmywa osady głównie z elementów węzła ciernego TSPC (tłok-sworzeń-pierścień-cylinder),

- tłumi drgania i zmniejsza hałaśliwość.

Znajdujący się w układzie smarowania silnika olej smarowy jest stale narażony na działanie wielu czynników, takich jak np.: wysoka temperatura, wysokie ciśnienie, które w znamienny sposób przyspieszają jego procesy utleniania i rozkładu. Niekorzystny wpływ na jakość oleju wywierają również takie zjawiska jak: rozcieńczenie oleju paliwem, przedostanie się do oleju wody z procesu spalania czy też zanieczyszczenie oleju cząsteczkami pyłu z powierzchni lub opiłkami metali pochodzącymi ze zużywanych części silnika.

Ze względu na fakt, że E85 jest stosunkowo nowym paliwem etanolowym na rynku światowym, zasadne jest prowadzenie badań, których celem będzie ocena jego wpływu na właściwości fizykochemiczne oraz użytkowe smarowego oleju silnikowego.

\section{Założenia prowadzonych badań}

Głównym celem prowadzonych badań było monitorowanie właściwości fizykochemicznych i użytkowych wytypowanego smarowego oleju silnikowego w klasie lepkości SAE 5W-30 i w klasie jakości ACEA A5/B5, spełniającego wymagania producenta FORD WSS-M2C913-C. Olej ten był eksploatowany w silniku badawczo-testowym Ford $1.8 \mathrm{~L}$
Duratec-HE PFI typu FFV (125 PS) MI4 (Euro IV), zasilanym paliwem etanolowym E85.

Założono, że właściwości oleju silnikowego będą monitorowane w trakcie prowadzonego testu silnikowego. Próbki do badań zostaną pobrane po 100, 600 i 1100 godzinach rzeczywistej pracy silnika. Po tych okresach pracy będzie możliwe 
zaobserwowanie wielokierunkowych zmian właściwości fizykochemicznych i użytkowych na skutek degradacji smarowego oleju silnikowego. Próbki przebadano w zakresie właściwości podanych w tablicy 1 .

Zgodnie $\mathrm{z}$ aktualnym stanem wiedzy jakość smarowego oleju silnikowego może być określona za pomocą szeregu testów, które obejmują laboratoryjną ocenę właściwości fizykochemicznych oraz ocenę właściwości w warunkach testów silnikowych. W czasie hamownianego testu silnikowego smarowy olej silnikowy narażony był na działanie różnych czynników prowadzących do stopniowej utraty niektórych właściwości użytkowych i eksploatacyjnych. Uzyskane wyniki badań analizowano pod kątem możliwych przyczyn zmian parametrów fizykochemicznych podczas wykonywanych testów silnikowych oraz potencjalnych skutków, jakie mogą mieć wpływ na jego właściwości użytkowe. W tablicy 2 zestawiono otrzymane wyniki badań pozwalające na przeprowadzenie oceny stanu smarowego oleju silnikowego.

Dla olejów silnikowych lepkość kinematyczną oznaczano w dwóch temperaturach: $40 \mathrm{i} 100^{\circ} \mathrm{C}$. Stanowi ona podstawowy wskaźnik oceny właściwości reologicznych olejów smarowych. Pozwala określić klasę lepkości oleju według odpowiednich klasyfikacji, potwierdzić zgodność oleju z wymaganiami normy oraz wyznaczyć wskaźnik lepkości oleju. Na tej podstawie można ocenić zależność lepkości oleju od temperatury oraz śledzić jej zmianę w czasie eksploatacji.

Lepkość kinematyczna oleju zmienia się w czasie eksploatacji w wyniku utleniania oleju (następuje wzrost lepkości),

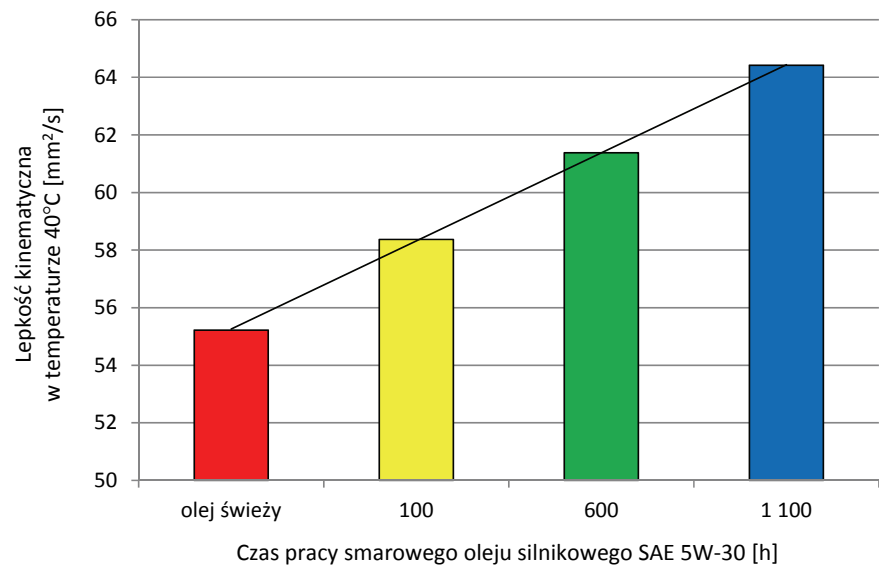

Rys. 2. Zależność lepkości kinematycznej smarowego oleju silnikowego SAE $5 \mathrm{~W}-30$ oznaczonej w temperaturze $40^{\circ} \mathrm{C}$ od czasu pracy destrukcji dodatków modyfikujących właściwości reologiczne (wówczas lepkość spada) lub zanieczyszczenia oleju innymi substancjami. Spadek lepkości następuje np. na skutek zanieczyszczenia oleju paliwem, a wzrost - produktami spalania. Zależność lepkości kinematycznej przedmiotowego oleju smarowego w temperaturach 40 i $100^{\circ} \mathrm{C}$ od czasu jego pracy zamieszczono na rysunkach 2 i 3 .

Trend zmiany lepkości kinematycznej oznaczonej w temperaturach $40 \mathrm{i} 100^{\circ} \mathrm{C}$ układa się w obu przypadkach w sposób analogiczny - powiększa się wraz ze wzrostem czasu eksploatacji przedmiotowego oleju silnikowego.

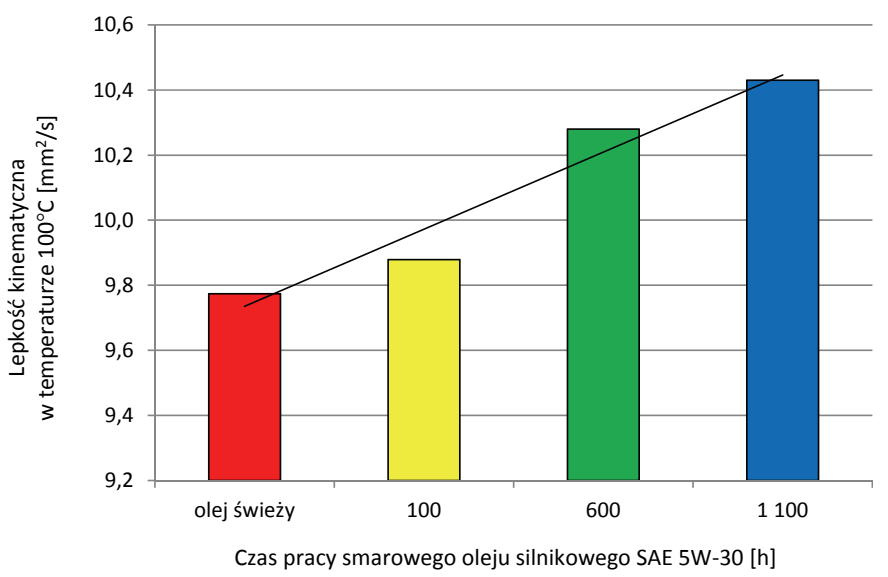

Rys. 3. Zależność lepkości kinematycznej smarowego oleju silnikowego SAE 5W-30 oznaczonej w temperaturze $100^{\circ} \mathrm{C}$ od czasu pracy 
Tablica 2. Wyniki badań właściwości fizykochemicznych smarowego oleju silnikowego SAE 5W-30 podczas testu hamownianego w silniku FORD 1,8 L DURATEC-HE PFI typu Flex Fuel, zasilanym paliwem etanolowym E85, po 100 godzinach pracy silnika

\begin{tabular}{|c|c|c|c|c|c|}
\hline Oznaczona cecha & Jednostka & Olej świeży & $\begin{array}{l}\text { Olej po } 100 \\
\text { godz. pracy } \\
\text { silnika }^{*}\end{array}$ & $\begin{array}{l}\text { Olej po } 600 \\
\text { godz. pracy } \\
\text { silnika }\end{array}$ & $\begin{array}{l}\text { Olej po } 1100 \\
\text { godz. pracy } \\
\text { silnika }^{*}\end{array}$ \\
\hline Lepkość kinematyczna w temperaturze $40^{\circ} \mathrm{C}$ & {$\left[\mathrm{mm}^{2} / \mathrm{s}\right]$} & 55,22 & 58,37 & 61,38 & 64,42 \\
\hline Lepkość kinematyczna w temperaturze $100^{\circ} \mathrm{C}$ & {$\left[\mathrm{mm}^{2} / \mathrm{s}\right]$} & 9,774 & 9,879 & 10,28 & 10,43 \\
\hline Wskaźnik lepkości & {$[-]$} & 164 & 156 & 156 & 150 \\
\hline $\begin{array}{l}\text { Lepkość dynamiczna HTHS (w temperaturze } 150^{\circ} \mathrm{C} \\
\text { i przy szybkości ścinania } 10^{6} \mathrm{~s}^{-1} \text { ) }\end{array}$ & {$[\mathrm{mPa} \cdot \mathrm{s}]$} & 3,80 & 3,23 & 3,19 & 3,00 \\
\hline $\begin{array}{l}\text { Lepkość strukturalna w temperaturze }-30^{\circ} \mathrm{C} \\
\text { Metoda CCS }\end{array}$ & {$[\mathrm{mPa} \cdot \mathrm{s}]$} & 3900 & 4300 & 6050 & 7500 \\
\hline $\begin{array}{l}\text { Odporność na ścinanie, spadek lepkości kinematycznej } \\
\text { w } 100^{\circ} \mathrm{C} \text { po } 30 \text { cyklach ścinania }\end{array}$ & {$[\%]$} & 2,45 & - & - & - \\
\hline Całkowita liczba zasadowa & {$[\mathrm{mg} \mathrm{KOH} / \mathrm{g}]$} & 11,1 & 10,1 & 6,8 & 6,1 \\
\hline Liczba kwasowa & {$[\mathrm{mg} \mathrm{KOH} / \mathrm{g}]$} & 2,8 & 2,9 & 3,2 & 4,7 \\
\hline Zawartość etanolu & {$[\%(m / m)]$} & 0,00 & 0,02 & 0,02 & 0,04 \\
\hline Zawartość osadów nierozpuszczalnych: & \multirow{3}{*}[\%(m/m)]{} & & & & \\
\hline - w pentanie & & 0,000 & 0,007 & 0,010 & 0,039 \\
\hline$-\mathrm{w}$ toluenie & & 0,000 & 0,001 & 0,002 & 0,025 \\
\hline Stopień oksydacji & \multirow{3}{*}[\mathrm{A}/\mathrm{cm}]{} & - & 19,3 & 34,6 & 55,9 \\
\hline Stopień nitratacji & & - & 16,9 & 42,6 & 68,0 \\
\hline Stopień sulfonowania & & - & 26,8 & 50,5 & 72,7 \\
\hline Zawartość sadzy & {$[\%(m / m)]$} & - & \multicolumn{3}{|c|}{ poniżej 0,1} \\
\hline Odporność na utlenianie w cienkiej warstwie & [min] & 69 & 40 & 18 & 14 \\
\hline \multicolumn{6}{|l|}{ Zawartość pierwiastków pakietowych: } \\
\hline - cynk & \multirow{5}{*}[\mathrm{ppm}]{} & 902,0 & 878,0 & 865,0 & 856,0 \\
\hline - wapń & & 3017,0 & 3022,0 & 2981,0 & 2980 \\
\hline - magnez & & 24,0 & 24,0 & 22,3 & 17,0 \\
\hline - fosfor & & 660,0 & 628,0 & 638,0 & 664,0 \\
\hline- bor & & 19,0 & 12,0 & 12,0 & 8,4 \\
\hline \multicolumn{6}{|l|}{ Zawartość pierwiastków zużyciowych i z zanieczyszczeń: } \\
\hline - żelazo & \multirow{12}{*}[\mathrm{ppm}]{} & 55,0 & 100,0 & 99,0 & 116,0 \\
\hline- glin & & 6,2 & 8,1 & 14,0 & 15,0 \\
\hline - miedź & & 5,4 & 6,8 & 6,8 & 6,9 \\
\hline - ołów & & \multicolumn{4}{|c|}{ poniżej 10} \\
\hline - bar & & \multicolumn{4}{|c|}{ poniżej 0,5} \\
\hline - chrom & & 0,6 & 1,2 & 1,8 & 2,8 \\
\hline- potas & & \multicolumn{4}{|c|}{ poniżej 10} \\
\hline - molibden & & 98,0 & 99,0 & 96,0 & 97,0 \\
\hline- sód & & 4,6 & 6,9 & 8,3 & 13,0 \\
\hline- nikiel & & \multicolumn{3}{|c|}{ poniżej 5,0 } & 0,62 \\
\hline - krzem & & 192,0 & 194,0 & 229,0 & 228,0 \\
\hline - cyna & & \multicolumn{4}{|c|}{ poniżej 10} \\
\hline
\end{tabular}

* Każde 100 godzin pracy silnika odpowiada przebiegowi $6000 \mathrm{~km}$ w warunkach rzeczywistej eksploatacji. 
Istotnym parametrem normatywnym oleju silnikowego jest wskaźnik lepkości, obliczany w oparciu o oznaczoną wartość lepkości kinematycznej w temperaturach 40 i $100^{\circ} \mathrm{C}$; im jest on wyższy, tym mniejszy jest spadek lepkości wraz ze wzrostem temperatury i dlatego należy śledzić jego zmianę w czasie eksploatacji oleju smarowego. Zaobserwowane zmiany przedstawiono na rysunku 4.

Wzrost lepkości kinematycznej świadczy o przebiegu procesów utleniania oraz zanieczyszczenia smarowego oleju silnikowego produktami degradacji, co przekłada się na spadek wskaźnika lepkości.

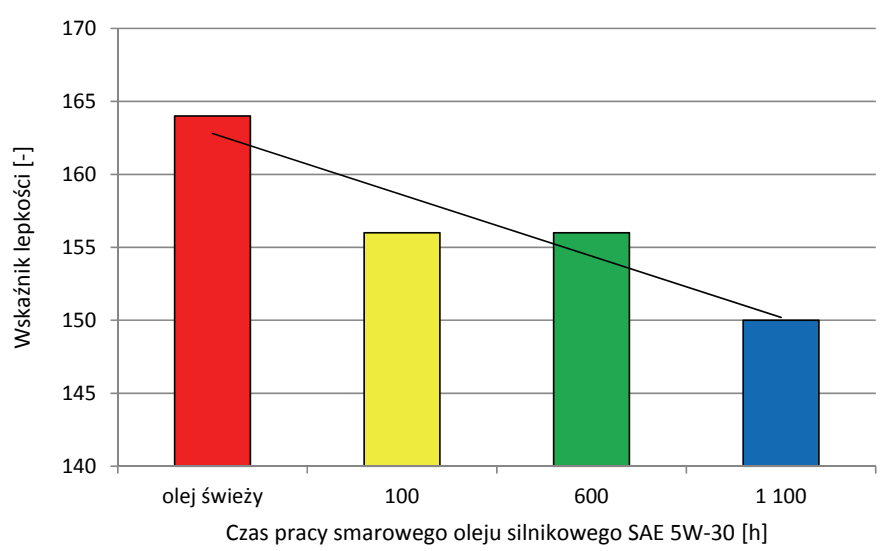

Rys. 4. Zależność wskaźnika lepkości smarowego oleju silnikowego SAE 5W-30 od czasu pracy

W chwili uruchomienia wychłodzonego silnika podstawowe znaczenie mają opory, które musi pokonać rozrusznik. W celu określenia, jaki udział ma opór wynikający ze wzrostu lepkości oleju, stosuje się prosty lepkościomierz rotacyjny o cylindrach współśrodkowych, nazywany symulatorem zimnego rozruchu (Cold Cranking Simulator - CCS).

Lepkościomierz CCS pozwala stwierdzić, czy lepkość dynamiczna oziębionego oleju silnikowego nie przekracza wartości uznanej za dopuszczalną, tzn. zapewniającej nadanie silnikowi odpowiedniej prędkości obrotowej przez rozrusznik zasilany prawidłowo naładowanym akumulatorem.

Wartość lepkości strukturalnej może się zmieniać wraz z szybkością ścinania, ponieważ wiele olejów smarowych w niskiej temperaturze przestaje być cieczami newtonowskimi (czyli takimi, które wykazują stałą lepkość dla wszystkich wartości szybkości ścinania) [13].

Zależność lepkości strukturalnej smarowego oleju silnikowego SAE $5 \mathrm{~W} / 30$ (ACEA A5/B5) w temperaturze $-30^{\circ} \mathrm{C}$ od czasu pracy przedstawia rysunek 5 .

Zaobserwowano wzrost lepkości strukturalnej CCS do poziomu znacznie powyżej wartości dopuszczalnej (maksymalnie do $6600 \mathrm{mPa} \cdot \mathrm{s}$ dla tej klasy lepkościowej). Skutkiem tego może być utrudniony rozruch wychłodzonego silnika lub wręcz brak możliwości jego uruchomienia.

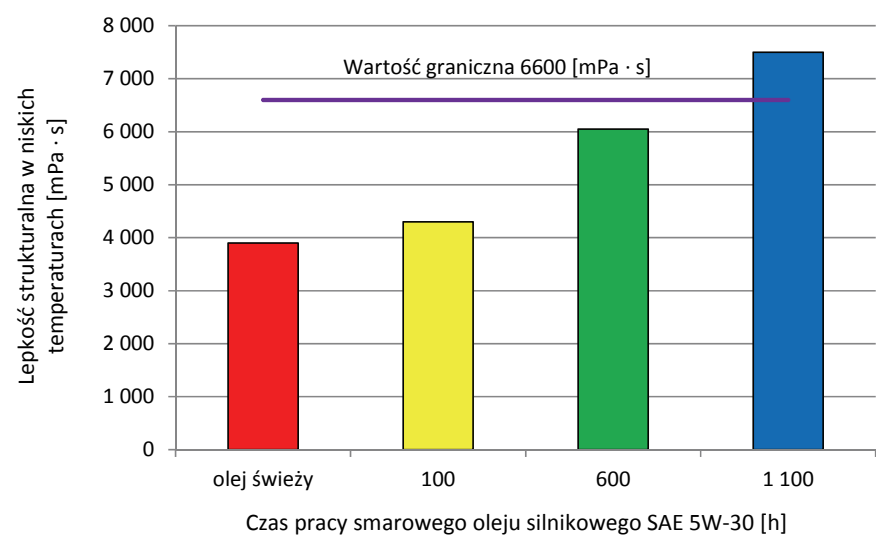

Rys. 5. Zależność lepkości strukturalnej smarowego oleju silnikowego SAE $5 \mathrm{~W}-30 \mathrm{w}$ temperaturze $-30^{\circ} \mathrm{C}$ od czasu pracy

W miarę wzrostu cieplnych i mechanicznych obciążeń silników spalinowych, a także w związku z rozpowszechnieniem olejów wielosezonowych, obejmujących coraz szerszy zakres klas lepkości, większą uwagę przywiązuje się do rzeczywistej lepkości oleju silnikowego w węzłach tarcia silnika. Stwierdzono, iż oleje silnikowe zestawiane przy zastosowaniu różnego typu dodatków lepkościowych, mimo że pokrywają identyczny zakres klas lepkości, w różnym stopniu zabezpieczają przed zużyciem elementów silnika pracujących w warunkach tarcia hydrodynamicznego, zwłaszcza łożysk ślizgowych [5].

Niektóre wiskozatory zmieniają skuteczność swojego działania. Szczególnie proces ten jest zauważany w obszarach intensywnego przemieszania się oleju w cienkiej warstwie, która rozdziela współpracujące ze sobą powierzchnie, np. przy powstaniu klina smarowego pomiędzy czopem i panewką po uruchomieniu nagrzanego silnika.

Lepkość dynamiczną HTHS w temperaturze $150^{\circ} \mathrm{C}$ i przy szybkości ścinania $10^{6} \mathrm{~s}^{-1}$ przedmiotowego oleju silnikowego oznaczono za pomocą lepkościomierza Ravenfielda o współosiowych stożkach. Wyniki oznaczeń przedstawiono na rysunku 6.

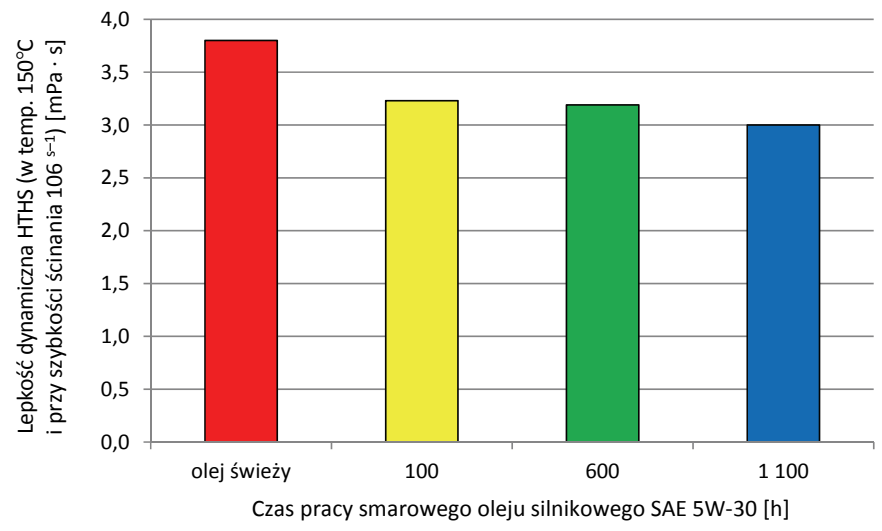

Rys. 6. Zależność lepkości dynamicznej smarowego oleju silnikowego SAE 5W-30 od czasu pracy 
Stwierdzono, że lepkość dynamiczna HTHS przebadanych próbek oleju silnikowego SAE $5 \mathrm{~W}-30$ nie przekraczała wartości granicznej (minimum $2,9 \mathrm{mPa} \cdot \mathrm{s}$ ), co gwarantuje utrzymywanie filmu smarowego na współpracujących elementach silnika nawet przy wysokich gradientach temperatur i szybkościach ścinania.

W miarę użytkowania smarowego oleju silnikowego jego zasadowe właściwości zostają zobojętnione substancjami kwaśnymi pochodzącymi z procesów spalania paliwa oraz procesów degradacji oleju. Liczba zasadowa współczesnych olejów silnikowych jest związana z ich klasą jakościową oraz rodzajem paliwa stosowanego do zasilania silnika spalinowego [13].

Produkty utleniania przedmiotowego silnikowego oleju smarowego oraz produkty z innych procesów jego degradacji doprowadziły do znacznego spadku całkowitej liczby zasadowej. Wskazuje to na spore obniżenie potencjału myjąco-dyspergującego i rezerwy alkalicznej oleju, istotnej ze względu na konieczność neutralizacji produktów kwaśnych, w tym głównie kwasów nieorganicznych pochodzących z procesów spalania paliwa oraz częściowo z procesów utleniania oleju i powodujących rozwój procesów korozyjnych na powierzchniach wewnętrznych elementów silnika. Potwierdzeniem tych zjawisk jest nie tylko spadek całkowitej liczby zasadowej, ale również duży wzrost liczby kwasowej (rysunek 7).

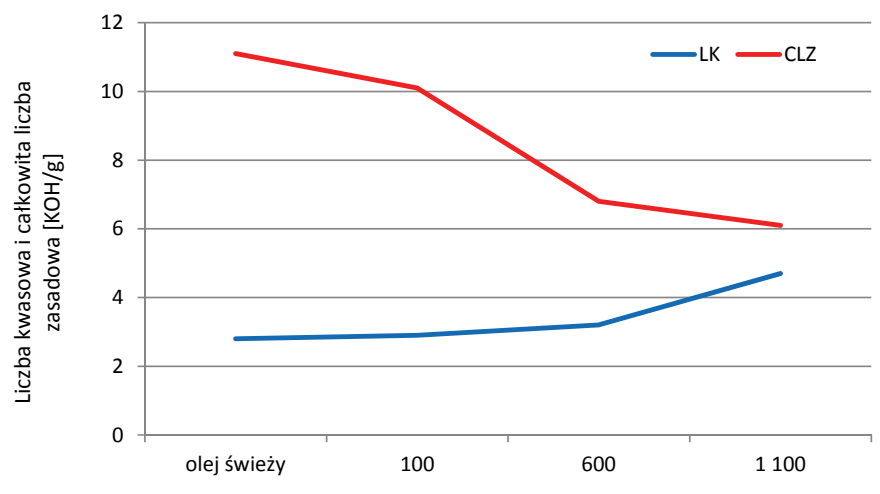

Czas pracy smarowego oleju silnikowego SAE 5W-30 [h]

Rys. 7. Zależność całkowitej liczby zasadowej i liczby kwasowej smarowego oleju silnikowego SAE 5W-30 od czasu pracy

Wzrost zawartości produktów utleniania przyczynia się do tworzenia różnego rodzaju osadów w różnych miejscach silnika (obiektu badawczego). Osady te mogą prowadzić do zatkania filtra oleju, ograniczenia przepływu oleju w kanałach olejowych oraz znacznego utrudnienia w rozprowadzeniu i smarowaniu elementów i podzespołów silnika (rysunek 8).

Wraz ze wzrostem czasu eksploatacji smarowego oleju silnikowego SAE 5W-30 (ACEA A5/B5) na skutek zachodzących procesów starzenia zaobserwowano wzrost zawartości produktów utleniania, nitratacji i sulfonowania (rysunek 9).

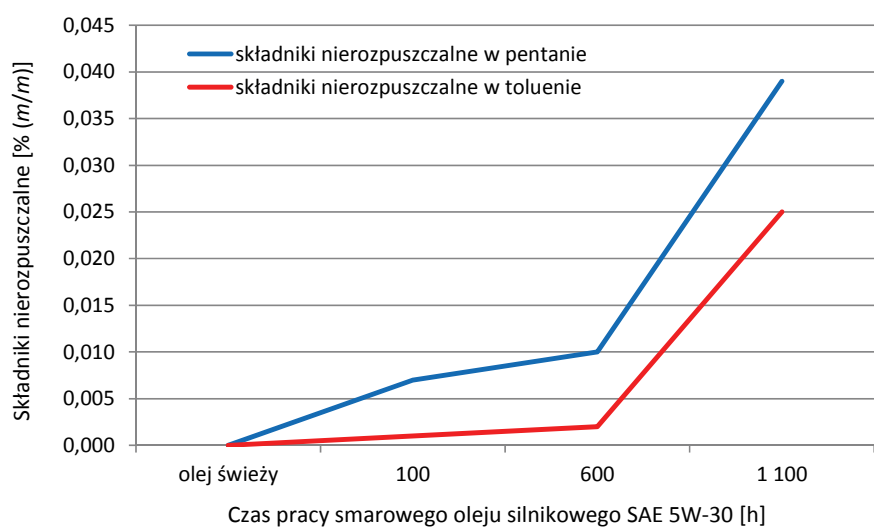

Rys. 8. Zależność zawartości substancji nierozpuszczalnych smarowego oleju silnikowego SAE 5W-30 od czasu pracy

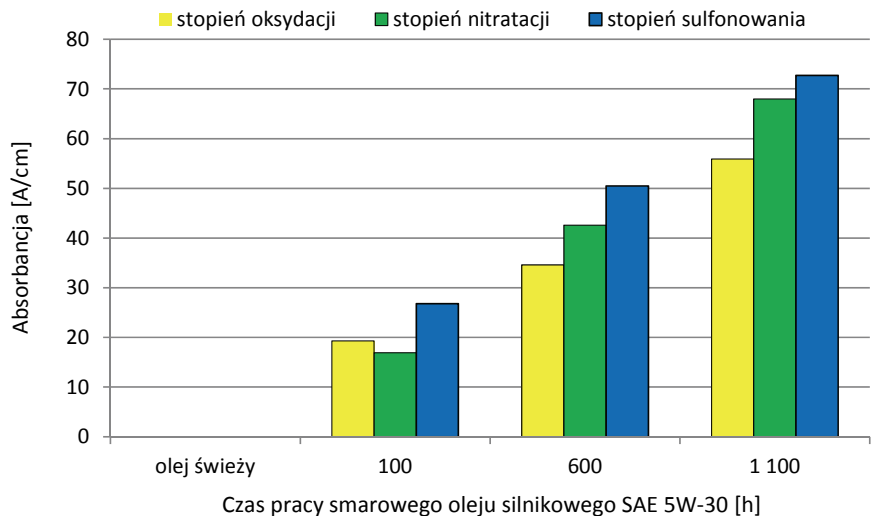

Rys. 9. Zależność stopnia oksydacji, nitratacji i sulfonowania smarowego oleju silnikowego SAE 5W-30 od czasu pracy

Ponadto potwierdzeniem zachodzących procesów starzenia smarowego oleju silnikowego podczas eksploatacji jest spadek jego odporności na utlenianie w cienkiej warstwie, co świadczy o wyczerpywaniu się przeciwutleniacza (rysunek 10).

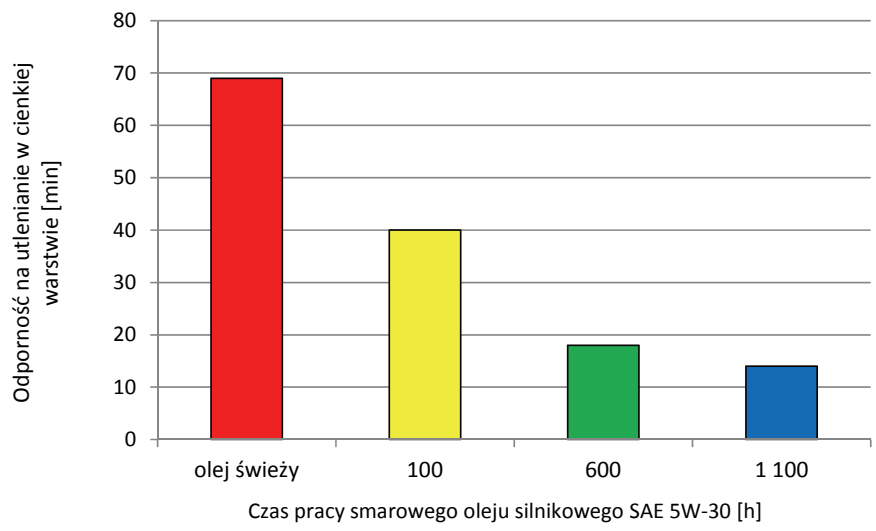

Rys. 10. Zależność odporności na utlenianie smarowego oleju silnikowego SAE 5W-30 od czasu pracy

Na podstawie wyników oznaczeń zawartości pierwiastków w eksploatowanym oleju silnikowym można określić stopień wyczerpywania się poszczególnych dodatków 
uszlachetniających ten produkt, jak również dokonywać wstępnej oceny stopnia zużycia elementów silnika. Na tej podstawie uzyskujemy także informację odnośnie poziomu zanieczyszczenia smarowego oleju substancjami pochodzącymi spoza układu (tj. pył) (rysunki 11 i 12).

W przypadku pierwiastków pakietowych obserwuje się ich nieznaczny spadek wraz z wydłużeniem czasu eksploatacji, co świadczy o naturalnym i stopniowym wyczerpywaniu się pakietu dodatków uszlachetniających.

W pracy dokonano oceny zawartości pierwiastków pochodzących ze zużycia współpracujących elementów składowych obiektu badawczego (silnika typu flex fuel) oraz oceny koncentracji pierwiastków wywodzących się z zanieczyszczenia oleju produktami pochodzącymi spoza układu badawczego. W przypadku tych pierwiastków zaobserwowano nieznaczny wzrost zawartości żelaza i miedzi (rysunek 13).

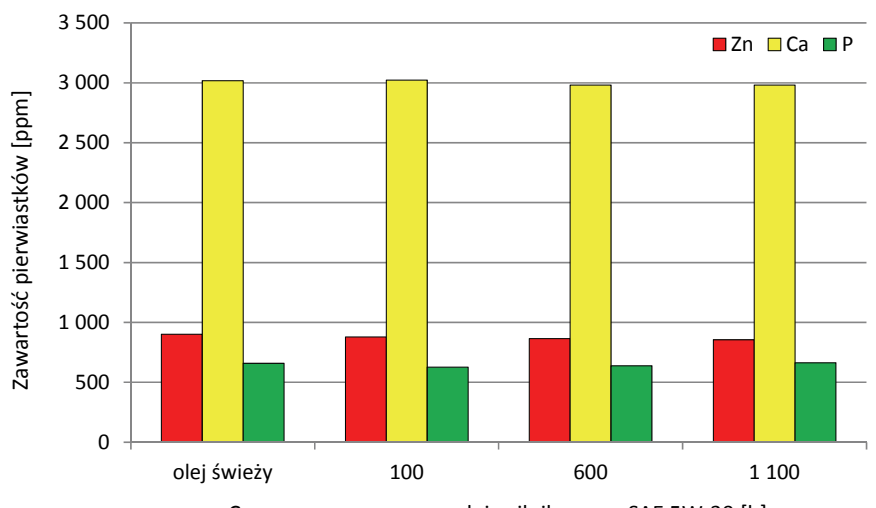

Czas pracy smarowego oleju silnikowego SAE 5W-30 [h]

Rys. 11. Zależność zawartości pierwiastków pakietowych cynku, wapnia i fosforu w smarowym oleju silnikowym SAE $5 \mathrm{~W}-30$ od czasu pracy

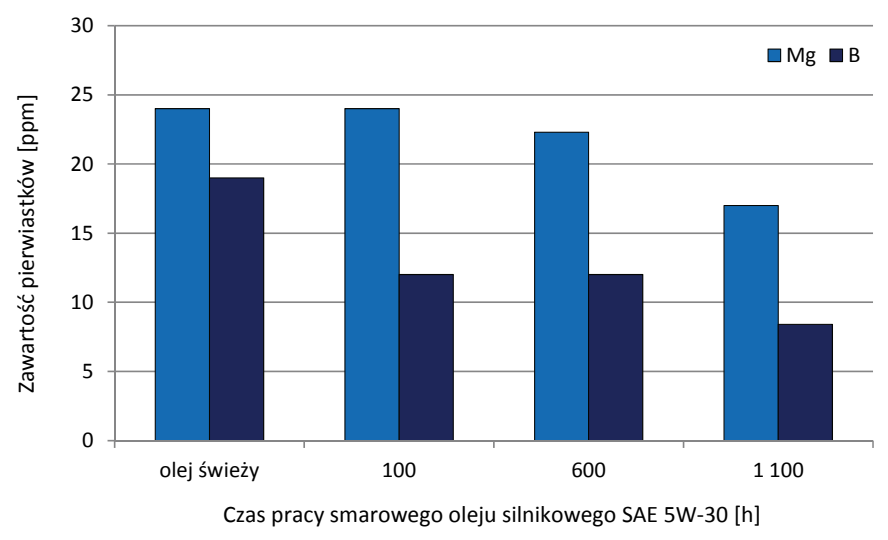

Rys. 12. Zależność zawartości pierwiastków pakietowych magnezu i boru w smarowym oleju silnikowym SAE 5W-30 od czasu pracy

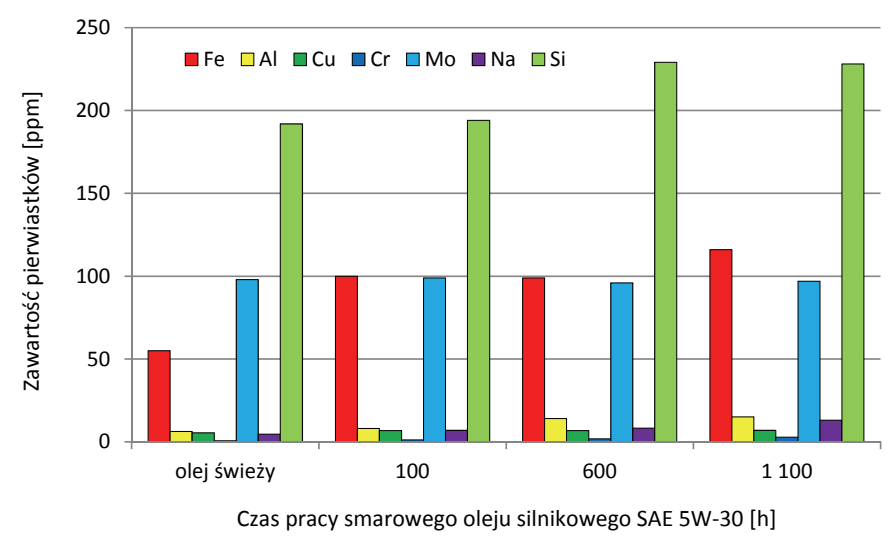

Rys. 13. Zależność zawartości pierwiastków zużyciowych i pochodzących z zanieczyszczeń $\mathrm{w}$ smarowym oleju silnikowym SAE $5 \mathrm{~W}-30$ od czasu pracy

\section{Wnioski}

1. W czasie prowadzonych badań następowała degradacja smarowego oleju silnikowego, na co wskazuje znaczne wyczerpywanie się dodatku przeciwutleniającego, czego potwierdzeniem jest duży spadek odporności na utlenianie oraz wzrost powstałych na skutek reakcji utleniania produktów, określony jako stopień oksydacji i sulfonowania.

2. Produkty powstałe na skutek degradacji smarowego oleju silnikowego w czasie jego eksploatacji doprowadziły do znacznego obniżenia potencjału myjącego i rezerwy alkalicznej oleju, istotnej ze względu na konieczność neutralizacji substancji kwaśnych. Potwierdzeniem tego jest nie tylko spadek całkowitej liczby zasadowej, ale również duży wzrost liczby kwasowej.

3. Obserwuje się nieznaczny spadek zawartości pierwiastków pakietowych wraz z wydłużeniem czasu eksploata- cji, co świadczy o naturalnym i stopniowym wyczerpywaniu się pakietu dodatków uszlachetniających lub o ich przekształceniu w inną formę. Dzięki nieznacznemu obniżeniu się potencjału dyspergującego substancje te nie aglomerują i nie wypadają w formie osadów, lecz pozostają w objętości oleju smarowego.

4. Wytypowany do badań olej silnikowy o klasie lepkości SAE 5W-30 i klasie jakości ACEA A5/B5 zachował swoje właściwości fizykochemiczne i użytkowe w zalecanym przez producenta okresie eksploatacji ze znacznym zapasem.

5. W czasie całego okresu eksploatacji przedmiotowy olej silnikowy zachował swoje właściwości przeciwzużyciowe, czego potwierdzeniem jest jedynie nieznaczny wzrost oznaczonej zawartości pierwiastków, tj. żelaza i miedzi. 
Artykuł nadesłano do Redakcji 29.06.2017 r. Zatwierdzono do druku 25.07.2017 r.

Artykuł powstał na podstawie pracy statutowej pt.: Wplyw oddziaływania biopaliw do silników z zapłonem iskrowym na degradację smarowego oleju silnikowego - praca INiG - PIB na zlecenie MNiSW; nr zlecenia: 0011/TE/15, nr archiwalny: TE-4101-11/15.

\section{Literatura}

[1] Biernat K., Jeziorkowski A.: Problemy zasilania współczesnych silników spalinowych wybranymi biopaliwami. Studia Ecologiae et Bioethicae 2008, nr 6, s. 307-329.

[2] Campbell E.: Setting a Fuel Quality Standard for Fuel Ethanol. Tender 2004, 18, IFQC June 2004.

[3] Dixon-Declève S., Klein T., Kiuru L., Vona C., Jones R.: The growing role of biofuels in global transport: From myth to reality. Henley Media Group Ltd, Fourteenth Edition.

[4] Jakóbiec J.: Olej silnikowy jako element konstrukcyjny silnika spalinowego. Nowoczesny Warsztat 2005, nr 6, s. 32-39.

[5] Podniało A.: Paliwa, oleje i smary w eksploatacji. Wydawnictwo Naukowo-Techniczne, Warszawa 2002, ISBN 83-204-2652-9.

[6] Sprawozdanie z działalności Agencji Rynku Rolnego w 2015 r. Biuro Analiz i Programowania, Warszawa 2016: http://www. arr.gov.pl/data/00167/sprawozdanie_arr_2015.pdf (dostęp: 13.04.2017).

[7] Stępień Z.: Wielokierunkowe badania wpływu paliw wysokoetanolowych na tworzenie osadów w silnikach z zapłonem iskrowym. Combustion Engines 2015, vol. 54, nr 3, s. 608-618, PTNSS-2015-3418.

[8] Stępień Z.: Zagrożenia eksploatacyjne stwarzane przez paliwa etanolowe dla silników o zapłonie iskrowym. [W:]
Paliwa alkoholowe dla transportu - uwarunkowania, badania i rozwój. Prace Naukowe Instytutu Nafty i Gazu - Państwowego Instytutu Badawczego 2015, nr 204, s. 68-94, DOI: 10.18668/PN2015.204.

[9] Strona internetowa: http://observer.cartajour-online.com/barosig/Interface_Standard/cart@jour.phtml?NOM_PROJE$\mathrm{T}=$ barosig $\&$ NOM_USER $=\&$ Langue $=$ Langue $2 \&$ Login $=\mathrm{O}$ K\&Pass=OK] (dostęp: 13.04.2017).

[10] Żółty M., Stępień Z.: Paliwa etanolowe w zastosowaniu do silników o zapłonie iskrowym. Nafta-Gaz 2016, nr 9, s. 761-769, DOI: 10.18668/NG.2016.09.12.

\section{Akty prawne i normatywne}

[11] Energy Policy Act z 1992 r., https://www.afdc.energy.gov/ pdfs/2527.pdf (dostęp: 21.05.2017).

[12] PN-C-04098 Przetwory naftowe - Oznaczanie lepkości dynamicznej HTHS olejów silnikowych lepkościomierzem Ravenfielda, 1994.

[13] PN-C-04150 Przetwory naftowe - Oznaczanie lepkości strukturalnej olejów $w$ niskich temperaturach symulatorem zimnego rozruchu (CCS), 2004.

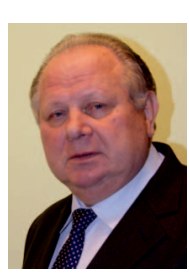

Prof. dr hab. inż. Janusz JAKÓBIEC

Profesor zwyczajny

Wydział Energetyki i Paliw,

Katedra Technologii Paliw

Akademia Górniczo-Hutnicza

al. Mickiewicza 30, 30-059 Kraków

E-mail:jjakobie@agh.edu.pl
Mgr inż. Magdalena ŻÓŁTY

Specjalista badawczo-techniczny w Zakładzie Oceny Właściwości Eksploatacyjnych; kierownik Laboratorium Badań Właściwości Użytkowych.

Instytut Nafty i Gazu - Państwowy Instytut Badawczy

ul. Lubicz 25 A, 31-503 Kraków

E-mail: magdalena.zolty@inig.pl 